Електронне наукове фахове видання "Ефективна економіка" включено до переліку наукових фахових видань України з питань економіки

(Категорія «Б», Наказ Міністерства освіти і науки України від 11.07.2019 № 975) www. economy.nayka.com.ua | № 1, 2021 | 28.01.2021 p.

DOI: $\underline{10.32702 / 2307-2105-2021.1 .94}$

UDC 004.94

O. Ivanova,

PhD in Economics, Associate Professor,

Associate Professor of the Department of Digital Economy and System Analysis,

Kyiv National University of Trade and Economics

ORCID ID: 0000-0002-0904-7468

\title{
STRUCTURAL MODELLING OF CRM SYSTEM OF TOURISM ENTERPRISES
}

\author{
О. М. Іванова, \\ к. е. н., доцент, доцент кафедри ициррової економіки та системного аналізу, \\ Київський наџіональний торговельно-економічний університет
}

\section{СТРУКТУРНЕ МОДЕЛЮВАННЯ СКМ СИСТЕМИ ТУРИСТИЧНИХ ПІДПРИЕМСТВ}

As tourism enterprises significantly depend on timely customer service due to the simplified operation of information systems and the circulation of information flows, CRM is necessary to apply for constant communication with customers. It is important to build its structural model to reflect the dynamism of information flows and ensure quality of the tourism product.

Analysis of recent research and publications has shown that the application of the CRM system in the activities of service enterprises is actively studied by both Ukrainian and foreign scientists. The main accent is made on justification and creation of a structural model of CRM as flexible and sensitive to external changes that affect the activities of the tourism enterprise to improve customer service and efficiency. The theoretical basis and methodological basis of the article consist of the works of Ukrainian and foreign scientists on CRM systems for customer service. Having received substantiated scientific research, the article uses theoretical generalization, analysis and synthesis to consider the features of CRM for tourism enterprises.

The interrelation between information system and service quality was analyzed. Due to informative nature of a tourism product, dynamics and intensity of information flows between tourism enterprises and customers, CRM was recognized as the necessary tool to communicate with clients, promotes their retention, and manage internal processes. CRM functions for tourism enterprises were formulated. The structural model of the tourism CRM functioning was designed, taking into account the information flows content. E-CRM provides wider services to be provided for customers. The importance and competitive advantage in using CRM system in the tourism enterprises are determined. The structural model of CRM system functioning is created, taking into account intensity and character of information flows in formation and sale of a tourist product. CRM efficiency indicators for tourism enterprises are determined.

Оскільки туристичні підприємства суттєво залежать від своєчасного обслуговування споживачів завдяки спрощеній роботі інформаційних систем та иүиркуляиії інформачійних потоків, CRM необхідна для постійного спілкування з клієнтами. Важливо побудувати ї̈ 
структурну модель, щзоб відобразити динамізм інформаційних потоків та забезпечувати якість туристичного продукту.

Аналіз останніх досліджень $і$ публікацій показав, щзо застосування CRM системи $у$ діяльності підприємств сфери послуг активно вивчається як украӥнськими, так $і$ іноземними науковиями. Основний акцент зроблений на обтрунтуванні і створенні структурної моделі CRM як гнучкої та чутливої до зовнішніх змін, щчо впливають на діяльність туристичного підприємства для покращення обслуговування споживачів та ефективності.

Теоретичну основу та методологічну основу статті складають роботи українських та зарубіжних вчених з CRM-систем для обслуговування споживачів. Отримавши обтрунтовані наукові дослідження, стаття використовує теоретичне узагальнення, аналіз та синтез для розгляду особливостей CRM для туристичних підприємств. Проаналізовано взаємозв'язок між інформаційною системою та якістю послуг. Через інформативність туристичного продукту, динаміку та інтенсивність інформаційних потоків між туристичними підприємствами та клієнтами, CRM визначено як необхідний інструмент для спілкування 3 клієнтами, ̈̈х збереження серед постійних та управління внутрішніми прочесами. Сформульовано функиії CRM для туристичних підприємств. Структурна модель функиіонування CRM для туризму була розроблена з урахуванням змісту інформаційних потоків. Е-CRM надає більш широкі послуги, щзо надаються споживачам. Визначено важливість і конкурентну перевагу у використанні CRM системи у діяльності туристичних підприємств. Структурна модель функціонування CRM системи з урахуванням інтенсивності і характеру інформачійних потоків у формуванні і продажі туристичного продукту. Зазначено показники ефективності CRM для туристичних підприємств.

Keywords: customer relationship; CRM; tourism enterprise; information system; structural model.

Ключові слова: взаємовідносини $з$ клієнтами; CRM; туристичне підприємство; інформаційна система; структурна модель.

Background. The organization and management of customer relations in tourism enterprises is an essential driver of business processes. Since such enterprises are significantly dependent on timely customer service through the streamlined operation of information systems and the circulation of information flows, these technologies serve for the permanent communication with customers. In turn, it provides significant benefits to a tourist enterprise. Thus, Minh and others endow customer relationship management (CRM) with significant competitive advantages and relevant organizational improvements [4]. This system corresponds to the needs and characteristics of tourism and the specifics of a tourist enterprise, in particular, the dynamism of information flows, orientation towards income generation, consumer value, development of a new or existing tourism product, and other characteristics.

Analysis of recent research and publications. Informational and organizational support of tourist products through information systems directly denotes tourism quality. The theoretical and practical evidences concerning the role of CRM and other informational systems are considered in the research of J. Park \& E. Jeong, B. Ahmed, M. L. Maati, B. Al Mohajir and others. Informational content of CRM includes the informational flows from social media and directly from communication with customers. These aspects are highlighted in the research of F. Javed \& S. Cheema, T. Prymak, M. Lutsenko. However, application of CRM in the daily activity of tourism enterprises relies on the offered options of the software, but the dynamism and changeability of tourism and appropriate businesses require systemic and structural approach to the design and adaptability of internal systems and information flows. Therefore, the development of customer relationship management (CRM) structure sensitive to the external changes will facilitate better communication with consumers and the formation of competitive advantages of tourism enterprises.

The purpose of the article is to design the structural model of CRM as flexible and sensitive to external changes affecting the activity of a tourist enterprise to improve its customer service and efficiency.

Material and methods. The theoretical basis and methodological background of the article comprise of the works of Ukrainian and foreign scientists on customer relationship management information systems and their usage for tourism services provided along with data analytics and promotion possibilities for tourism enterprises. Gaining scientific reasonable research, the paper applies theoretical generalization, analysis and synthesis to address the specifics of CRM for tourism enterprises. Striving for the maximum proximity of the developed positions to the specifics of tourism enterprises is of particular importance for the practical vector of the study that will contribute to further research of the stated issue. 
Results. Definition of CRM and its role for business operations vary depending on the specifics of its application and the scope of structural options. Researchers identified that CRM guides the processes and procedures responsible for communication with customers. Economic and technical views on CRM concentrate on application of information technologies in management of customer service [4]. N. V. Minh and other researchers [4] indicated its tight connection with segmentation of key targeted audience and allocation of appropriate resources applied to this audience. In addition, the tools of data mining and warehousing enhance effective decision-making processes in CRM [8]. Cutting-edged innovations have improved the approach to management of external communication.

Ukrainian patterns of CRM usage are such that CRM as a corporate information technology provides communication with customers through organized and customized collaboration of sales, marketing, and customer service. The development of information technologies that expand the possibilities for closer interaction with consumers stimulates and enhances collection of customer data via Internet to generate wide analytical decisions on reliable information, provides quality support of emailing and ranging of customers, etc. Moreover, the information systems of customer relationships reflect the level of quality and the patterns of its management in the tourism enterprises. Information systems like CRM should be integrated in total management of service quality as the tool of tourism enterprise to stay sensitive to consumer engagement, satisfaction and service perceptions (fig.1).

\section{Tourism Service Quality via CRM}

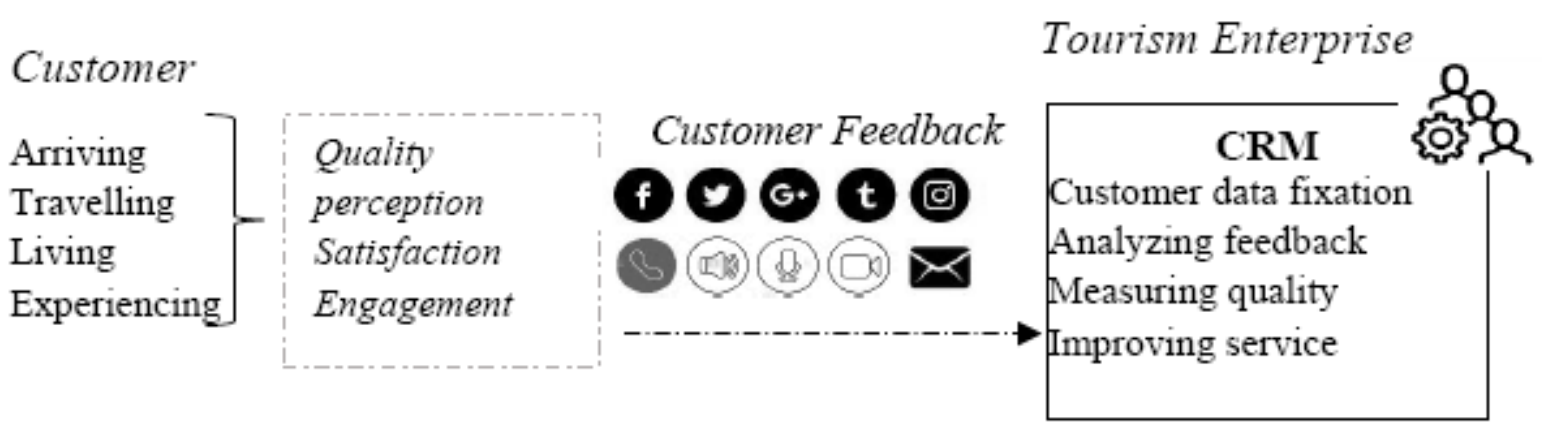

Fig. 1. The place of CRM in the tourism service quality management Source: developed by the author

The quality of tourist services, which are inextricably linked with the information base, information processes, and information technologies, is determined by the ability to correctly, promptly and timely generate and process information about a tour, to serve tourists, to provide them with organizational and informational support throughout the entire period of tourist product consumption via communication channels. As the tourist product has an informational nature, the use of various information systems creates a precondition for the high quality of a final tourist product. Therefore, the tourism value and quality denote the efficiency and contribution of information system of tourism enterprises. Furthermore, organization and provision of tourism services enable enterprises to improve its internal interrelationships and processes, starting from communication with customers. In turn, hardware, software, data/information, and system of CRM provide the same opportunities to improve the quality of the tourism service.

The role of CRM in tourism industry of Ukraine is conditioned by the necessity to interact with customers directly and continuously. Opportunity to expand these options to the analysis and management of information flows between consumers and a tourism enterprise makes this information system crucial for the integrated management of tourism business. The system is consistent with the overall objectives of the tourism business and promotes consumer retention. The mechanism of increasing loyalty due to the development of CRM also requires considerable research, as this relationship with consumers reduces the market and financial risks inherent in tourism and ensures long-term profit.

Based on the mentioned information, we may generalize the functions of CRM in a tourism enterprise according to its technological and informational role:

- Drives the sales in tourism;

- Collects the valuable data on customer behaviour, decisions, preferences, responses, patterns, etc.;

- Improves internal unity of business processes of a tourism enterprise;

- Consolidates document data of customers while issuing a tourist voucher or other related procedures;

- Automates customer data research, workflow management, and manual procedures of tourism managers;

- Provides tourism managers with rapid information technologies to avoid human errors;

- Ensures high level of quality management in a tourism enterprise;

- Provides the dynamism of customer service in accordance with the features of adaptive and phased formation of the tourist product.

The information system of CRM performs its primary and additional functions according to its compositional elements. D. Nam, J. Lee, \& H. Lee [6] attested that CRM should also include analytical components related to business analytics. Thus, the functional blocks of the CRM will provide an integrated systemic approach to receiving and processing consumer information and the appropriate response of a tourist enterprise applied such CRM (fig. 2). 


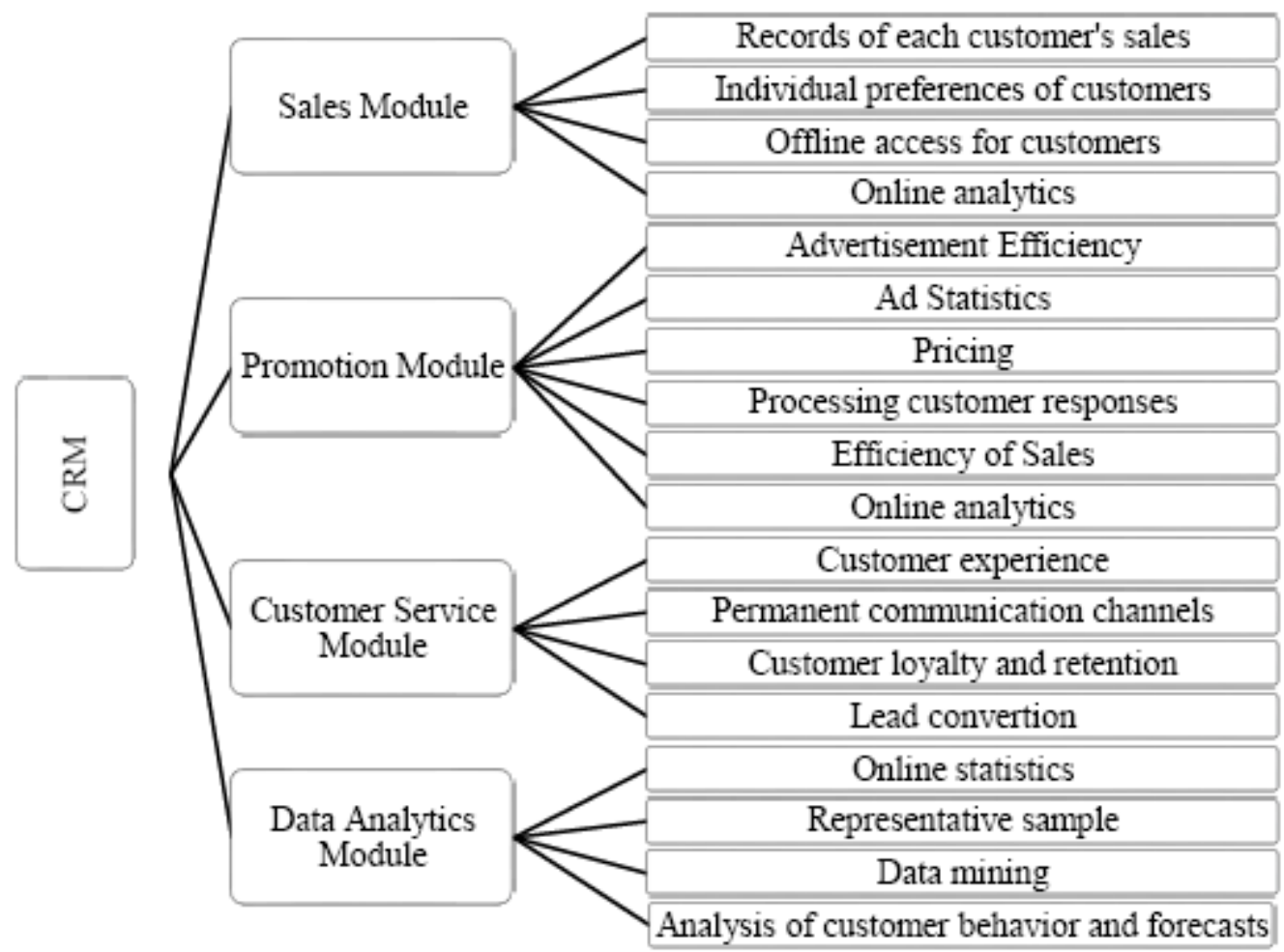

Fig. 2. Functional blocks of CRM structure in tourism Source: developed by the author

Functional modules ensure analytical operations, diverse information processes, the formalized customer service procedures, marketing research, and other operational aspects inherent in the use of software for support and communication with consumers. The compositional structure of this information system includes those functional components that correspond to the financial, technological, informational, technical, social, and general economic opportunities of a tourism enterprise. The list of functions and options provided in figure 2 may be supplemented by other additional functions and opportunities.

The core element of CRM system is the communication between tourist enterprises and the consumers of tourist products. The information circulating between these two participants of tourism market refers to all attributes of a tourist product. The number of such information flows depends on the goals of promotion, quality of CRM applied, and collaboration with other partners composed a tourist product. The character of such information flows predetermines the main working aspects in the CRM system (fig.3).

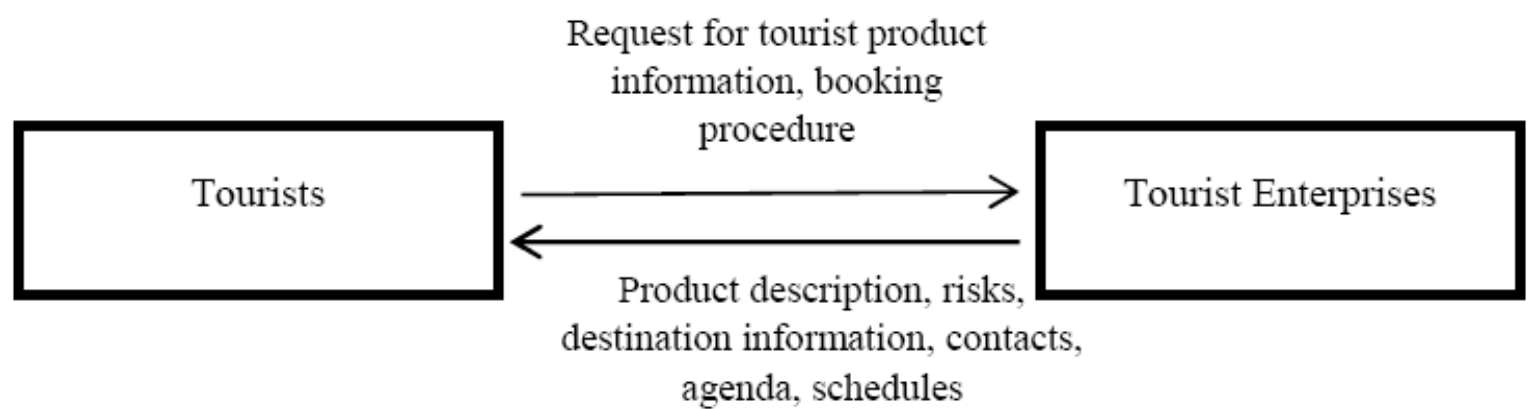

Fig. 3. Content of main working information flows in CRM

Source: developed by the author

Integrated CRM includes more additional content related to promotion, advertising, and sales. Therefore, the common mechanism of interaction with customers should correspond with the next informational rationales of communication, which determine the optimal composition of the information system and cover all aspects of interaction with consumers:

- Consumer preferences in the tourism type, solvency, period and duration of the tourist route;

- Personal information, data on insurance and financial position, contacts;

- Advertising information, promotions;

- Reviews, comments, clarifying information; 
- Consultations during the service, consultations during the consumption of a tourist product, mediation consultations.

Thus, the functional blocks of the CRM will provide an integrated systemic approach to receiving and processing consumer information and the appropriate response of a tourist enterprise using such CRM. Its online form substitutes expensive desktop version. Online form of CRM allows reducing costs related to customer service and tightening customer relationship, providing customization of communication tools, etc. The whole mechanism of ECRM integrates the channels of communication, the content, and diverse services provided via Internet.

E-CRM is used to manage customer relationship by using the Internet and web applications. The main issues are provision of adequate and relevant information about tourist products timely and according to the customers' queries [1]. Application of E-CRM in tourism enables the range of services provided: product;

- Customer service, including booking and order tracking, customization and configuration of a tourist

- Streamline services, including provision of information flows, communication with partners, etc.

- Extra services, including online courses and sales.

The introduction of E-CRM system in the tourism enterprise's activities contributes to a better integration of marketing information and promotion of tourism products in internal processes of a tourism enterprise. In addition, companies collect and preserve the communication history of managers in consumers, place orders, record calls, organize employment and tasks for subordinates, monitor task deadlines, manage tour organization, and generate reports online. These features add value to a tourism service, improve the customer service speed and quality for the existing tours, and provide flexibility in changing new tours directly in the service process. However, relying on ECRM limits the possibilities of a company to regulate own information flows, control work processes.

Criteria that determine the economic efficiency of the CRM system for a tourism enterprise include time costs on customer service; time costs for changing an existing tour; time costs for collecting marketing information; the range of monitored indicators; the number of controlled segments and the number of consumers per segment; level of conversion of potential customers into loyal customers; loyalty rate; sales rate; communication intensity rate and other indicators.

CRM should have proper design to meet the needs of a tourism enterprise, intensify the communication, and improve customer service. All the components should provide information for systematic market research through CRM analytics, which ensures comprehensive understanding of customer behavior and forecasts of future purchases through CRM [2]. The components of CRM constitute the whole structure of information system applied to implement CRM plans, process big data, manage further business processes, and drive tourism product sales.

Any information system must be adaptive to the changes in the market, consumer behavior, management decisions and macroeconomic trends. Since the CRM information system is the compositional structure of interrelated autonomous functional modules, its modelling will make it possible to determine the role of each component in providing high-quality tourism services and the tourist product as a whole. By applying case technologies to the construction of a functional-structural model of CRM system, some key nodes are identified for further transformations and consideration of the approaches to the CRM use in a tourist enterprise (fig.4).

Incoming data refer to personal data for identification of local or new customers and preparation of official documents, while customer preferences are additional sources of information for a tourism enterprise. The incoming information flows are used further in all modules of the CRM information system, as they support full information support and customization in all economic processes and stages of formation, correction, and sale of a tourist product.

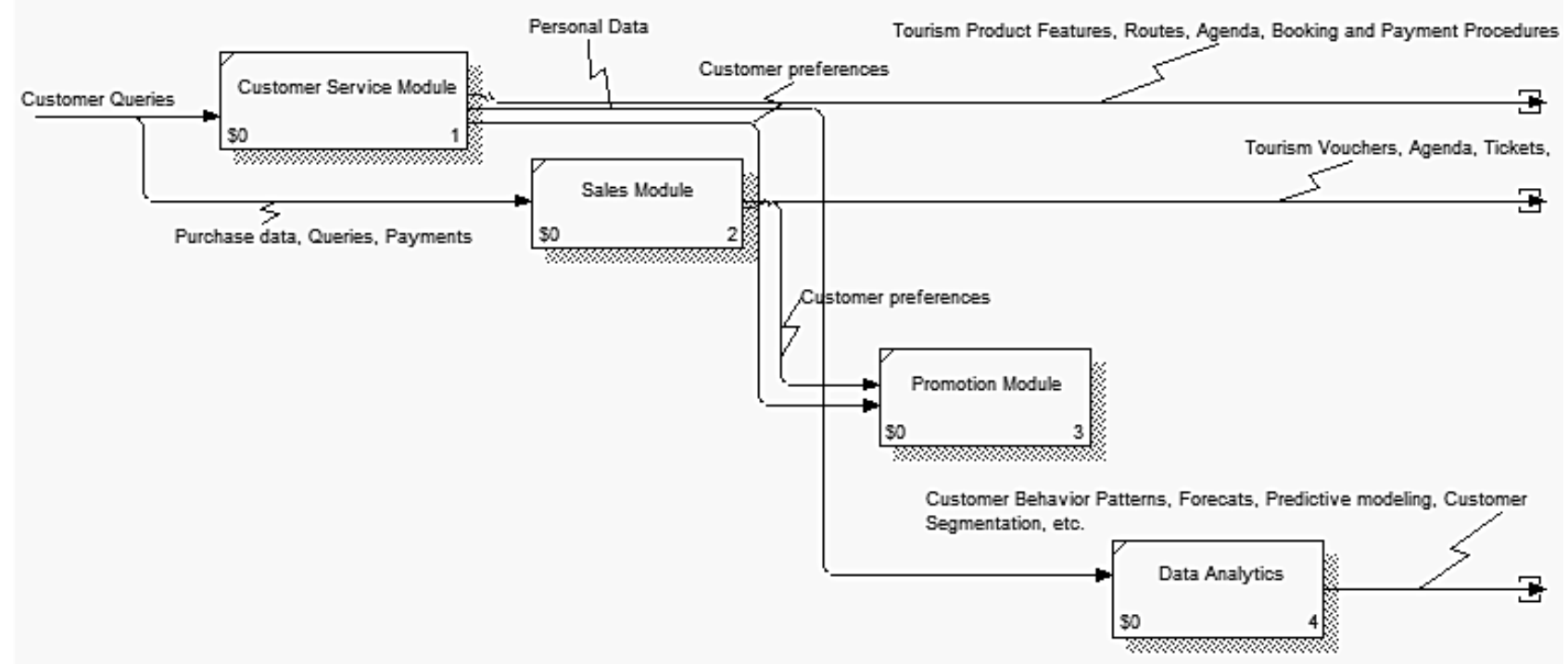

Fig. 4. Structural model of the tourism CRM

Source: developed by the author 
The sequence of information passing through the functional modules of the information system corresponds to the optimal distribution of the data volume across all services of a tourism enterprise. The data in the form of oral appeal, a phone call, an electronic request through mail or a social network are received through the consumer service module. The output of this module is the tourism managers' tasks, a tour details, plan and routes, reservations, transfer details, and any clarifications between consumers and managers. This module works with both loyal and potential customers.

The sales module is expected to achieve all the economic goals and benefits of a tourism enterprise, which targets the larger profits in the market. Due to the sales module, the CRM system helps the tourism company to plan, implement, and accompany sales; organize and monitor the transparent management of contractual relationships with customers, and optimize the throughput of sales channels. CRM keeps complete information about customers. And due to the integration with the customer service module, the system identifies the preferences of a particular customer, which generates valuable data for the data analysis module. Maintaining the sales module, the company carries out the sales procedures and records information for its further transfer to partners. In addition to interpreting ready-made and upcoming contractual obligations with existing and potential consumers, this module creates product-segment and cross-sales matrices, classifies consumers into appropriate segments, and identifies potential interests.

The promotion module helps a tourism enterprise to optimize and organize the management of marketing service. The module serves as a tool for disseminating information about tourism offers, managing and promoting a tourism product portfolio, structuring a range of tourism products, promoting bonus programs to regular customers, and enhancing consumer experience. Due to outgoing information about promotions, tourism operator or agent improves the work on sales taking into account price regulation, ensuring their flexibility, optimizing tourism services and destinations in the chosen tourism package, and analysing customer behaviour. The place of the promotion module in the CRM structure determines the sales outcomes. It reinforces the results of sales of tourism products and creates an information base for further data analysis.

The module of data analytics is the structural component comprises all software components of CRM installed or of remote access, which process and analyses the data of customers and external market environment to improve, adopt, and streamline the effective business decisions. This module is the smart component, which implies data mining and simple analytical processing. Since tourism operators and agents have become more sophisticated in communication with customers, the necessity and IT opportunities to transform or explore their databases for analytical decisions got more pronounced. Implications of the data analytics module are customer behavior patterns, forecasts of sales and customer responses, predictive modelling of influence of factors on a tourism company's sales and consumer behavior, consumer segmentation, profitability analysis, personalization of tours, tracking of the effectiveness of using tours, and so on. The company can track trends in the sales of the tourism product range or behavioral trends (seasonality, hot tours). The module allows tourism companies to personalize and segment consumers according to the history of purchases, the construction of a tourist route, and tourist preferences.

CRM analytics is an important data analysis tool that predetermines the hidden relationships between customer data and sales data. Thus, tourism companies of Ukraine may predict the behaviour of tourists a few steps ahead and get prepared to increase the level of customer satisfaction [3]. Since the tourist product requires individual approach, taking into account the personalization of tourist services and taking into account the personal wishes of tourists, CRM analytics in a special module will help identify the weaknesses in the organization and formation of a tourist package.

Due to the fact that tourism companies use analytical calculations, they are aware of external and internal changes. CRM analytics improves the productivity and efficiency of relations with consumers, assesses the level and quality of consumer service, and verifies market data. In addition to objective advantages, the CRM system of tourism enterprises is affected by the disadvantages of this module dedicated to data analytics as one of the actual issues of dynamic IT development (fig. 5). 


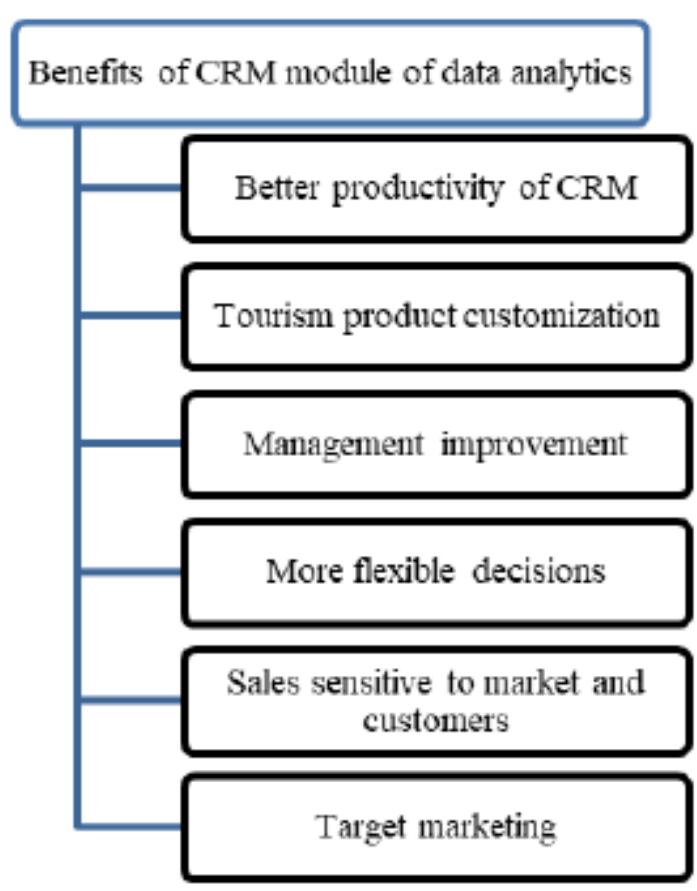

Challenges of CRM module of data analytics

Problematic integration with existing modules

Additional requirements to database maintenance, update, and utilization

Fig. 5. Benefits and challenges of CRM module of data analytics Source: developed by the author

The developed promotion module of the CRM system of a tourism company should also rely on the diversity of marketing interactive tools for communication with customers and formation of quality customer relationships. Therefore, the tracking mechanism of CRM system should include the statistics of customer activity in Internet (fig. 6).

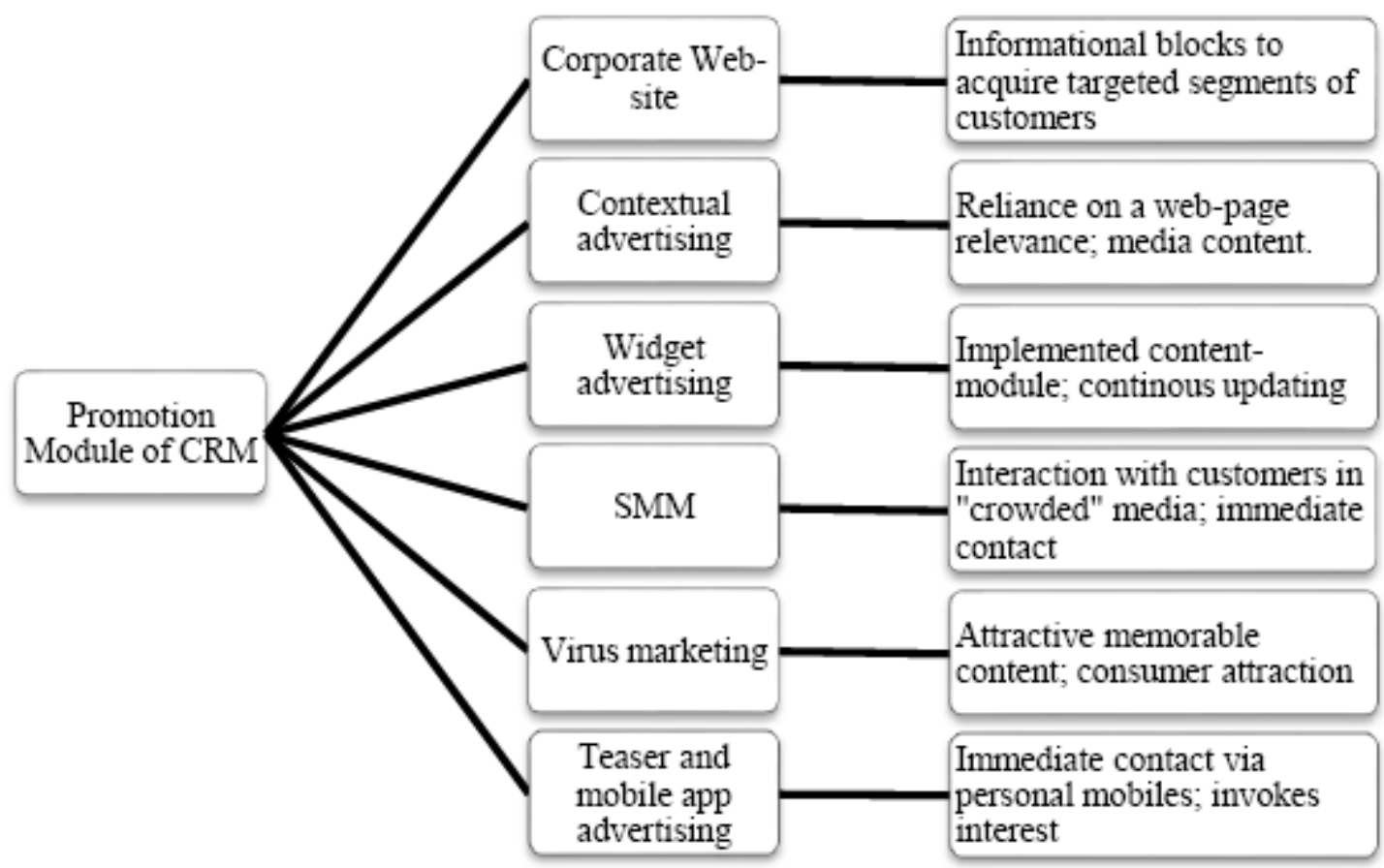

Fig. 6. Communication tools in promotion module of tourism CRM system Source: developed by the author based on [8]

The mentioned types of advertising should correspond with CRM as the affiliate applications and integration elements. Importing the statistics of consumer visits or clicks or likes or other forms of response on the Internet will serve an informational basis for analysing data and evaluating the effectiveness of content and the mentioned communication channels. Transferring data of consumer responses into the CRM database will supplement sales data and add value for analytical decision-making processes in tourism enterprises. As the CRM system is a large architecture with numerous operations, a secure algorithm should accompany its filling, where the number of modules and the mechanism of their interaction should be as simple as possible. Therefore, four components of CRM compositional structure performing wide range of operations and functions for tourism companies were offered. 
Conclusion. The role of CRM in tourism of Ukraine is vital due to its opportunities for this type of business. While tourism companies intend to attract more attention and increase number of loyal tourists, their internal information systems and economic processes require improvement of tourist product quality and better customization. CRM applied by tourism enterprises ensures tight connection with tourists and potential clients, timely delivery of information, proper and quality allocation of internal resources, dynamic changeability of internal processes, etc. Attributes of CRM as an information system influence on common quality level of tourist services. It means that the more advanced and sensitive CRM, the more efficient communication with consumers is for tourism enterprises. Functionality of CRM in the activity of tourism enterprises indicates the necessity in optimal compositional structure of CRM. Connected customer service module, promotion module, sales module, and data analytics module constitutes the complete and unique CRM adjusted to tourism specificity and the problems of Ukrainian operators and agents with market appearance and long-term customer relationships. Estimation of the CRM system efficiency will influence the success of a tourism company and its sales growth. Implementation of special communication tools as the measures of promotion in CRM structure through the final statistics of customers' activity is believed to improve communication with customers and wider representation in the market.

\section{References.}

1. Ahmed, B. Maati, M. L. B. and Al Mohajir, B. (2015), "The effectiveness of the intelligence e-crm application in enhancing positive customer relationships", International Journal of Scientific and Technology Research, 7 $(4)$, pp. 150-152. Available

https://www.researchgate.net/publication/287816902_The_Effectiveness_Of_The_Intelligence_ECRM_Application_In_Enhancing_Positive_Customer_Re-

2. Chiang, $\bar{F}$. and Sitaramachandran, S. (2015), "A data quality framework for customer relationship analytics", International Conference on Web Information Systems Engineering, Springer, Cham, pp. 366-378. DOI: 10.1007/978-3-319-26187-4_35.

3. Javed, F. and Cheema, S. (2017), "Customer satisfaction and customer perceived value and its impact on customer loyalty: the mediational role of customer relationship management", The Journal of Internet Banking and Commerce, pp. 1-14, Available at: https:/www.icommercecentral.com/open-access/customer-satisfaction-andcustomer-perceived-value-and-its-impact-on-customer-loyalty-the-mediational-role-of-customer-relationshipmanagement.php?aid=85790 (Accessed 14 January 2021).

4. Minh, N. V. Pavelkova, D. Phan, T. Phu, Q. and Van Nguyen, N. (2017), "Customer relationship management (CRM) in small and medium tourism enterprises: a dynamic capabilities perspective", Tourism and hospitality management, vol. 1, no. 24, pp. 1-24. DOI: 10.20867/thm.24.1.11.

5. Kampani, N. and Jhamb, D. (2020), "Analyzing the role of e-CRM in managing customer relations: A critical review of the literature", Journal of Critical Reviews, vol. 4, no. 7, pp. 221-226, Available at: http://www.jcreview.com/fulltext/197-1584793457.pdf (Accessed 20 December 2020).

6. Nam, D. Lee, J. and Lee, H. (2019), "Business analytics use in CRM: A nomological net from IT competence to CRM performance", International Journal of Information Management, vol. 45, pp. 233-245, Available at: https:/www.sciencedirect.com/science/article/abs/pii/S0268401217308812 (Accessed 20 December 2020).

7. Park, J. and Jeong, E. (2019), "Service quality in tourism: A systematic literature review and keyword network analysis", Sustainability, vol. 13, no. 11, pp. 3665, Available at: https://www.researchgate.net/publication/334212299_Service_Quality_in_Tourism_A_Systematic_Literature_Review_ and_Keyword_Network_Analysis (Accessed 20 December 2020).

8. Prymak, T. and Lutsenko, M. (2017), "Effective internet marketing tools in tourism management", Molodyj vchenyj, vol. 51, no. 11, pp. 758-763. Available at: http://nbuv.gov.ua/UJRN/molv_2017_11_186 (Accessed 14 January 2021). 